\title{
Archaeological Investigations at the Tobert Potter and Harriet Ames Cabin (41MR51) on Potter's Point, Caddo Lake
}

Timothy K. Perttula

Heritage Research Center, Stephen F. Austin State University

Follow this and additional works at: https://scholarworks.sfasu.edu/ita

Part of the American Material Culture Commons, Archaeological Anthropology Commons, Environmental Studies Commons, Other American Studies Commons, Other Arts and Humanities Commons, Other History of Art, Architecture, and Archaeology Commons, and the United States History Commons

Tell us how this article helped you.

This Article is brought to you for free and open access by the Center for Regional Heritage Research at SFA ScholarWorks. It has been accepted for inclusion in Index of Texas Archaeology: Open Access Gray Literature from the Lone Star State by an authorized editor of SFA ScholarWorks. For more information, please contact cdsscholarworks@sfasu.edu. 


\section{Archaeological Investigations at the Tobert Potter and Harriet Ames Cabin (41MR51) on Potter's Point, Caddo Lake}

\section{Creative Commons License}

\section{(c) (1) (8)}

This work is licensed under a Creative Commons Attribution-NonCommercial 4.0 International License 


\title{
ARCHAEOLOGICAL INVESTIGATIONS AT THE ROBERT POTTER AND HARRIET AMES CABIN (41MR51) ON POTTER'S POINT, CADDO LAKE
}

by

\author{
Timothy K. Perttula
}

\section{INTRODUCTION}

This paper discusses recent archaeological investigations at the Robert Potter and Harriet Ames cabin site (41MR51) on Caddo Lake at Potter's Point. The cabin site represents a relatively intact mid-nineteenth century archaeological deposit from a Northeast Texas cultural resource of considerable historical significance.

The site was located by Mr. Claude McCrocklin and members of the Louisiana Archaeological Society in the summer of 1992. The artifacts collected from these limited investigations were then turned over to the author for study as the first step in assessing the site's archaeological character and preservation potential.

\section{HISTORICAL BACKGROUND}

Robert Potter and Harriet Ames settled at Potter's Point on Caddo Lake in about 1839 (Pearson et al. 1993:42; Ames n.d.; Caddo Free Press, March 28, 1839). When they settled on Potter's headright "there was hardly a settler from near Sabine to the Sulphur Fork of Red River" (Ford 1963:27). Their nearest neighbors were Alabama Indians who lived in a small village about 2.5 miles north of Potter's Point (Pearson et al. 1993:Figure 8). These Alabama apparently had migrated to the Potter's Point peninsula in 1804.

The Potter cabin was built on a high bluff overlooking Caddo Lake. Harriet Ames (n.d.:16) described Potter's Point as a "picturesque promontory which overlooked a sheet of limpid water, dotted with islands, and losing itself in the haze of the distance." She (Ames n.d.:19) further stated that "our house stood upon a jutting promontory, that rose into a hill set in the midst of one of the grandest timber belts in Texas." Half way down the 
bluff was a spring of "crystal clear water;" the Potter's cut steps down the bank to the spring (Ames n.d.:31). This spring is shown as Ames Spring on modern maps of Caddo Lake.

Robert Potter was killed by a band of Regulators in March 1842. The so-called Regulator-Moderator war of Northeast Texas was a major social upheaval involving hundreds of families throughout what is now mainly Marion, Harrison, Panola, Shelby, and San Augustine counties (Webb 1952, II:458). This 1839-1844 war pitted citizens who wanted a moderation of the vigilantism (Moderators) against armed bands of citizens (Regulators) intent on banishing lawlessness and lawbreakers (even suspected lawbreakers) at any cost. Robert Potter was a leader of the Moderator faction north of the Sabine River.

Harriet buried Robert Potter on a "beautiful knoll on the hill in front of the house" (Ames n.d.:33). ${ }^{1}$ Figure 1a and $1 \mathrm{~b}$ indicate the same relationship between the Potter cemetery and the historic component at 41MR51, the Potter house site.

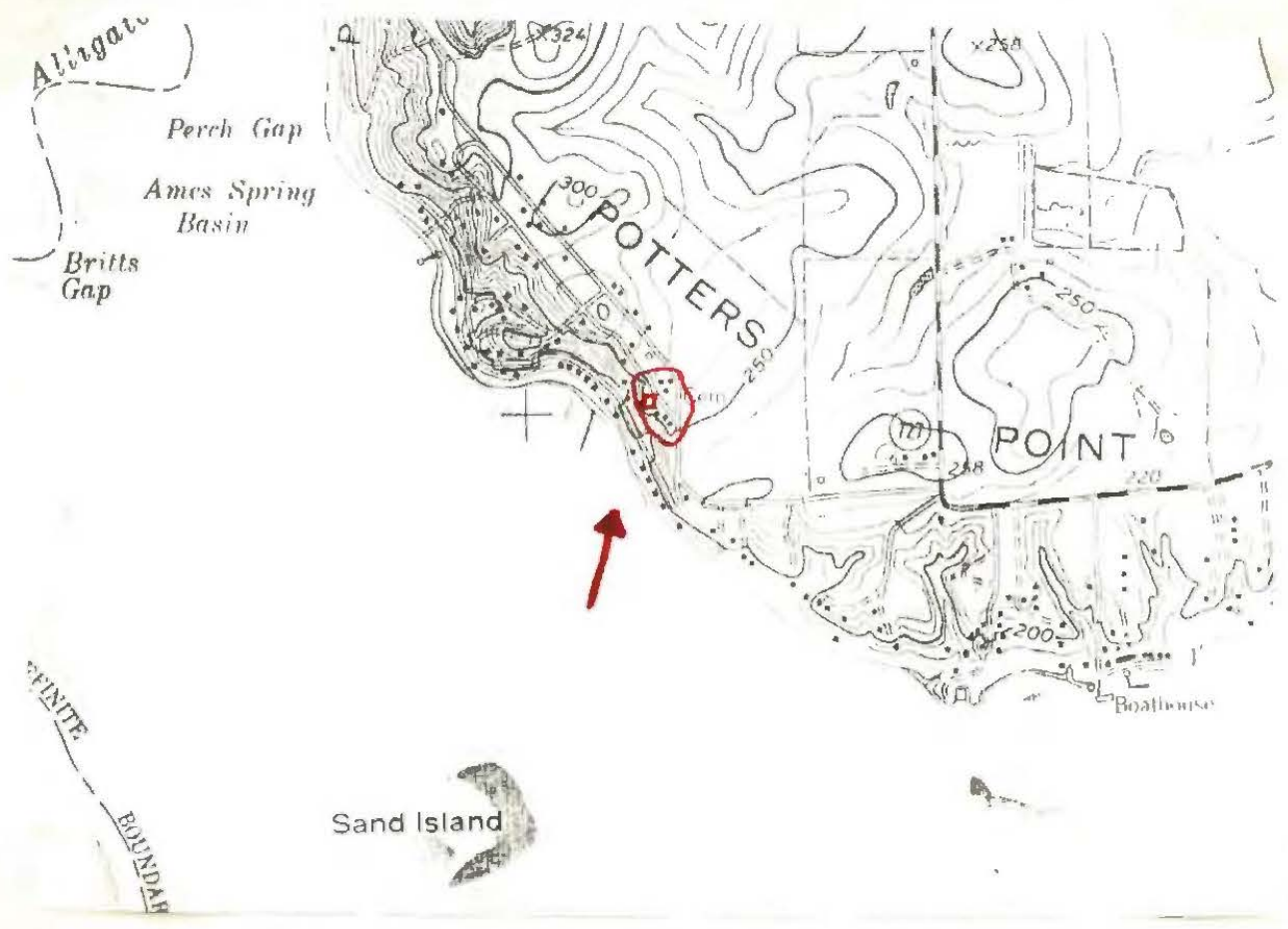

Figure 1a. Location of Site 41MR51 at Caddo Lake.

1 Potter's body was subsequently exhumed and moved to the state cemetery in Austin, Texas. 


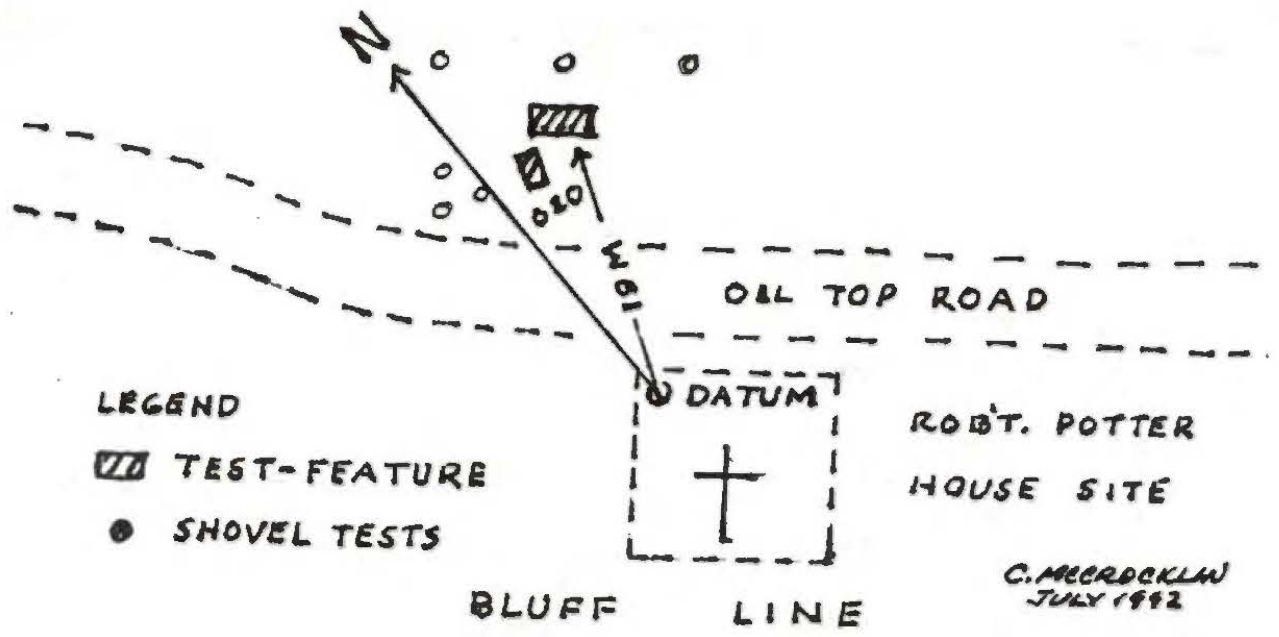

Figure 1b. Plan of test excavations at Potter house site.

Harriet married Charles Ames of Clarksville, Texas, on August 23, 1842 (Webb 1952, I:41). They continued to live at the farm on Potter's Point for many years, and then Harriet lived on at the farm after her husband's death. Ames (n.d.:40) states that she lived on the property for forty years, that is, until about 1879 . Archeological materials recovered from the site suggest that the Potter site was not occupied after Harriet Ames moved away in the late 1870 s to New Orleans.

\section{INVESTIGATIONS}

The Robert Potter and Harriet Ames cabin site is located within the previously recorded site 41MR51, initially recorded by Jon L. Gibson of Southern Methodist University in 1968 as part of a shoreline survey of Caddo Lake (Gibson 1969). Gibson (1969:24-26) makes no mention of an Historic Anglo-American occupation at the site, 
instead describing it as an extensive Early Caddoan (ca. A.D. 800-1200) period settlement on the Potter's Point bluff (see Figure 1a).

A few nineteenth century artifacts were recovered from site 41 MR.51 in 1974 by Gulf South Research Institute (1974:76), including refined earthenwares, glass fragments, and a portion of a marble tombstone. The historical significance of these artifacts was not recognized at that time.

The Anglo-American archaeological component was located by Claude McCrocklin and members of the Louisiana Archaeological Society in 1992. Nineteenth century archaeological materials were noted in the surface of the oil top road that runs immediately north of the Potter Cemetery, and were also recovered in shovel tests and two $1 \times 2$ meter units about 19 meters north-northeast from the north corner of the cemetery (see Figure 1b). The test units were along what was the northeast drip line of a log cabin, and the hearth and chimney fall area was located in three shovel tests west of the test units (Claude McCrocklin, 1992 personal communication).

\section{ARTIFACT ASSFMBLAGE}

A total of 72 historic artifacts were recovered from the Potter-Ames cabin in test excavations and road surface collections (Table 1). Most of the materials recovered are midnineteenth century European (English) kitchen/domestic ceramics, principally whitewares produced after 1830 , with a smattering of tableware, glass containers, structural and architectural items (nails, daub, and window glass), and horse and stable gear (a horseshoe nail). 
Table 1.

Artifact Assemblage from the Robert Potter and Harriet Ames

Cabin Investigations

\begin{tabular}{lcc}
\hline Artifact Type & Test Excavations & Surface Collection \\
\hline Porcelain & 5 & - \\
Plain Whiteware (WW) & 8 & 6 \\
Hand-painted WW & 1 & 6 \\
Annular WW & - & 5 \\
Transfer-printed WW & 6 & 1 \\
Shell-edged WW & 2 & 1 \\
Ironstone & - & - \\
Stoneware & 2 & - \\
Bottle glass & 5 & - \\
Table Knife & 1 & - \\
Window glass & 1 & - \\
Daub & 2 & - \\
Cut nails & 19 & 19 \\
Horseshoe nail & 1 & - \\
\hline
\end{tabular}

\section{$\underline{\text { Ceramics }}$}

The ceramics were sorted into refined earthenwares (whitewares and ironstone), porcelain, and stonewares following the definitions in Majewski and O'Brien (1987:115129). Whitewares represent about 81 percent of the ceramics, followed in frequency by porcelain (11.6 percent), stoneware (4.7 percent), and ironstone ( 2.3 percent).

Porcelain is the most expensive ceramic type represented in the collection (see Spencer-Wood's [1987] cup-plate and bowl index values where the porcelain cost index is 5.4 on a scale from 1 to 6 ). One of the porcelain sherds is from a cup with fine greenyellow lines hand-painted on the interior of the cup.

The ironstone sherd (dating from ca. 1840-1910) is from a thick, plain, plate. The 14 plain whiteware sherds are from bowls and plates, most of which probably had decorations on them (see below). 
Transfer-printed whitewares, a relatively expensive type of ceramic vessel being manufactured in the period from ca. 1840 to 1870 , are common at the Potter-Ames cabin. Black, blue, red, purple, and green transfer prints are present from plates, bowls, and cups, and the colors are bright with fine detail. Although the sherds are small, patterns used for the transfer prints depict classical and romantic pastoral landscapes (Figure 2). Both of these characteristics in the transfer-printed whitewares are typical of English ceramics manufactured between ca. 1830 and the Civil War (Majewski and O'Brien 1987:145).

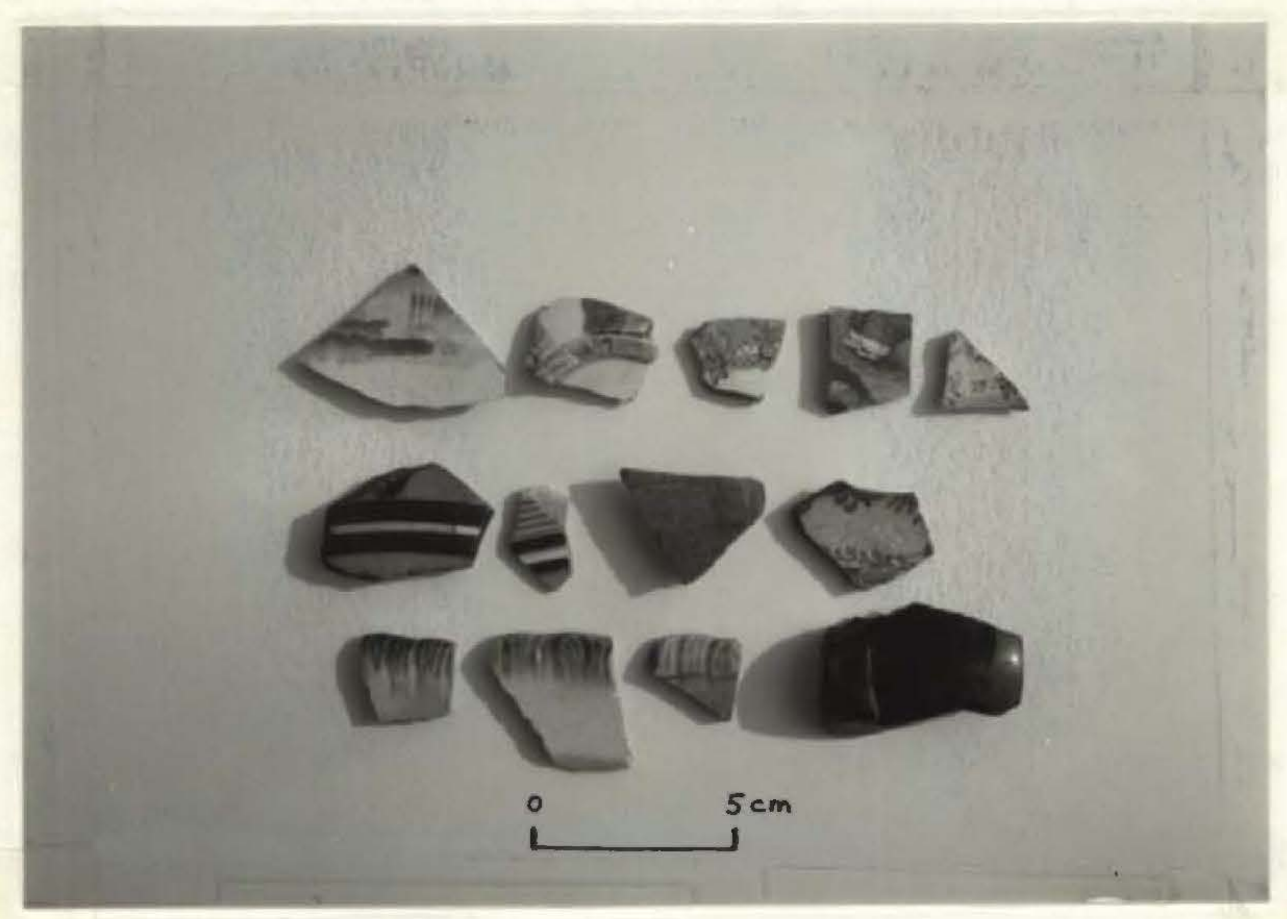

Figure 2. Selected Artifacts from the Potter-Ames house site at 41MR51.

Among the 12 transfer-printed sherds, five have blue colors and three have purple transfer prints, followed by red $(\mathrm{N}=2)$, green $(\mathrm{N}=1)$, and black $(\mathrm{N}=1)$. In Texas sites, blue and purple transfer-printed ceramics are quite common between ca. 1830 to 1870 . 
Only one hand-painted whiteware sherd was recovered from 41MR51 (see Table 1). It has a thick-line or "peasant" style that uses broad brush strokes and bright green, black, red, blue, and earthen colors in polychrome floral motifs on cups and saucers. Hand-painted whitewares were popular in Texas through the time of the Civil War.

The annular ware sherds from 41MR51 have black and white bands over the sherd body along with marbelized patterns just under the rim. The marbelized patterns were made by scrolling together two or more colors into a trailing "worm"-like design, a dripped or "combed" design, or agate-like, shaded circles dubbed "cat's eye." Again, annular wares were most commonly manufactured from ca. 1840-1870.

The last type of decorated whiteware is shell-edged plates. Blue or green color bands were hand-painted over a relief design with a "shell-edge" motif (Majewski and O'Brien 1987:148). Two of the three shell-edged sherds have cockled rims, which Moir (1987a) dates pre-1840 in Texas, while the other has a non-cockled rim dated at other Texas sites between ca. 1840-1865. The pre-1840 shell-edged sherds were recovered from the test excavations, and thus indicate the likely preservation of archaeological deposits coincident with the initial occupation of the Potter cabin in about 1839.

The two stoneware sherds are from salt-glazed jars or crocks. These vessels have an external salt vapor with an interior natural clay slip. Lebo (1987:140) has shown that these stonewares increased in popularity in Texas beginning about 1850 until about 1870 , then they declined considerably in popularity by 1900 .

\section{Bottle glass}

The bottle glass represents fragments of hand-blown commercially-manufactured containers, principally intoxicants (such as wine, ale, or brandy). None of the bottle sherds have diagnostic finish, decorative, advertising, or basal characteristics that would permit specific identifications of container contents or precise periods of bottle production. 
However, information regarding the color of the bottle glass sherds from 41MR51 is informative concerning temporal ranges and vessel use.

There are four dark green bottle glass sherds from containers for champagne or wine. The dark glass color was thought to protect wines and liquors from harmful sunlight. In general, these types of containers were manufactured between ca. 1840 to 1870 (Jones and Sullivan 1985:79).

The other bottle glass sherd has an aqua color. Aqua-colored glass bottles of the mid-nineteenth century typically contained medicinal extracts, culinary items, or pharmaceutical products (Jones and Sullivan 1985).

\section{Table Knife}

A table knife fragment in the assemblage represents the use, loss, and/or discard of kitchen flatware (i.e., forks, spoons, and knifes) at 41MR51.

\section{Window Glass}

The single piece of aqua window glass was $1.38 \mathrm{~mm}$ in thickness. Moir's (1987b) window glass thickness formula suggests that this thin piece of window glass may have been manufactured about 1830; the pane must have then been brought to the site sometime later.

Daub

Two pieces of daub were recovered in the test excavations at the cabin (see Table 1). The daub represents fired pieces of mud that were used as chinking for the space between the logs of the building and in the chimney, along with rocks, saplings, and other materials. When and if a structure burned, the mud (and any impressions of sticks, leaves, and twigs) would have been baked, preserving the impressions in the pieces of daub. The daub from 41MR51 has impressions of sticks and twigs. 
$\underline{\text { Nails }}$

The 19 nails are machine square cut forms; no wrought or wire nails are present in the assemblage. As late as 1880 , machine cut nails dominated the nail market in the U.S. with over 75-80 percent total sales. Conversely, Jurney (1987:90) notes that by 1895 sites were dominated by the presence of wire nails used for construction purposes.

The cut nails are common forms ranging in size from $6 \mathrm{~d}$ to $12 \mathrm{~d}$ (pennyweight). Cut nails of these sizes were probably used in wood roofing and for framing superstructural elements of the log pen structure(s) at the site.

\section{Horseshoe nail}

A single iron horseshoe nail from the test excavations indicates that horses were used and stabled at the site by the Potter's.

\section{Summary of the Artifact Assemblage}

The small assemblage of historic cultural materials from 41MR51 is believed to be from the cabin or home site of Robert Potter and Harriet Ames. This assemblage represents a discrete sample of ca. 1840-1870 domestic artifacts from the yard of the cabin. The few dated material items of whiteware and bottle glass are consistent with the ca. 1840-1870 occupation span indicated by historical sources; there are no artifacts in the collection that would represent a post-1870s use of the cabin or this small part of Potter's Point. It is likely that the material items preserved at the Potter-Ames cabin were obtained from the bustling steamboat town of Jefferson, Texas, a few miles west of Caddo Lake (Pearson et al. 1993:49). 


\section{CONCLUSIONS}

In July 1992, the location of the Robert Potter and Harriet (Potter) Ames home site was identified by Claude McCrocklin, Jacques Bagur, and members of the Louisiana Archaeological Society on a promontory across an oil road from the burial place of Robert Potter. The site is some 30 meters above Caddo Lake, and the blufftop setting overlooks a broad expanse of Caddo Lake.

Although parts of the home site were disturbed by construction of the road some years ago, limited shovel testing and hand excavations indicate that structural features and yard deposits are preserved on the north side of the road. The small artifact sample recovered from the site documents an occupation from ca. 1840 to 1870 , with mainly kitchen/domestic and structural/architectural artifacts identified from the site.

The Robert Potter and Harriet Ames cabin site contains important archaeological and historical information concerning early Texas history, particularly relating to the AngloAmerican settlement of the Caddo Lake area. It also has strong associations with Robert Potter, the first Anglo-American settler of the region, former congressman from North Carolina, a signer of the 1836 Texas Declaration of Independence, Secretary of the Texas Navy, a Senator in the Fifth and Sixth Congress of the Texas Republic, and a leader of the Moderator faction in the Regulator-Moderator war in Northeast Texas (Webb 1952, II:401). The Potter-Ames site is also of particular importance to the early history of Texas women because of the details of 40 years of life there preserved in a manuscript written by Harriet Ames (Ames n.d.) and preserved in the legal records of the state of Texas. In sum, the site is an important example of Texas' heritage, and it is strongly recommended that it be preserved and protected for the future enjoyment of the citizens of Texas.

\section{ACKNOWLEDGEMENTS}

I would like to thank Claude McCrocklin for providing the artifacts from the PotterAmes cabin site for study. Claude, Jacques Bagur, and Bob D. Skiles also provided useful 
comments on an earlier draft of this paper, along with information from various historical sources unfamiliar to the author.

\section{REFERENCES}

Ames, Harriet A.

n.d. The History of Harriet A. Ames during the Early Days of Texas. Typescript.

\section{Caddo Free Press}

March 28, 1839. Shreveport, Louisiana.

Ford, John Salmon

1963 Rip Ford's Texas. Edited by Stephen B. Oates. University of Texas Press, Austin.

Gibson, Jon L.

1969 Archaeological survey at Caddo Lake, Louisiana and Texas. Contributions in Anthropology No. 6. Southern Methodist University, Dallas.

Gulf South Research Institute

1974 Red River Waterway, Louisiana, Texas, Arkansas and Oklahoma: Mississippi River to Shreveport, Louisiana; and Shreveport, Louisiana to Daingerfield, Texas. Environmental Analysis, Volume 5: Archeology, History and Culture. Gulf South Research Institute, Baton Rouge.

Jones, Olive and Catherine Sullivan

1985 The Parks Canada Glass Glossary for the description of containers, tableware, flat glass, and closures. Studies in Archaeology, Architecture and History. National Historic Parks and Sites Branch, Parks Canada, Environment Canada, Ottawa, Ontario.

Jurney, David H.

1987 Cut and Wire Nails: Functional and Temporal Implications. In Historic Buildings, Material Culture, and People of the Prairie Margin: Architecture, Artifacts, and Synthesis of Historic Archaeology, edited by David H. Jurney and Randall W. Moir, pp. 84-96. Richland Creek Technical Series, Volume V. Archaeology Research Program, Institute for the Study of Earth and Man, Southern Methodist University. Dallas.

Lebo, Susan A.

1987 Local Utilitarian Stonewares: A Diminshing Artifact Category. In Historic Buildings, Material Culture, and People of the Prairie Margin: Architecture, Artifacts, and Synthesis of Historic Archaeology, edited by David H. Jurney and Randall W. Moir, pp. 121-142. Richland Creek Technical Series, Volume V. Archaeology Research Program, Institute for the Study of Earth and Man, Southern Methodist University. Dallas. 
Majewski, Teresita and Michael J. O'Brien

1987 The Use and Misuse of Nineteenth Century English and American Ceramics in Archaeological Analysis. In Advances in Archaeological Method and Theory, Volume 11, edited by Michael B. Schiffer, pp. 97-209. Academic Press, Orlando.

Moir, Randall W.

1987a Refined Earthenwares and Rural Ceramic Traditions. In Historic Buildings, Material Culture, and People of the Prairie Margin: Architecture, Artifacts, and Synthesis of Historic Archaeology, edited by David H. Jurney and Randall W. Moir, pp. 97-120. Richland Creek Technical Series, Volume V. Archaeology Research Program, Institute for the Study of Earth and Man, Southern Methodist University. Dallas.

1987b Socioeconomic and Chronometric Patterning of Window Glass. In Historic Buildings, Material Culture, and People of the Prairie Margin: Architecture, Artifacts, and Synthesis of Historic Archaeology, edited by David H. Jurney and Randall W. Moir, pp. 7381. Richland Creek Technical Series, Volume V. Archaeology Research Program, Institute for the Study of Earth and Man, Southern Methodist University. Dallas.

Pearson, Charles E., Jacques Bagur, and James Duff

1993 Identification and Analysis of Historic Watercraft in the Shreveport, Louisiana, to Daingerfield, Texas, Navigation Project. Coastal Environments, Inc., Baton Rouge.

Spencer-Wood, Susan M.

1987 Miller's Indices and Consumer-Choice Profiles: Status-Related Behaviors and White Ceramics. In Consumer Choice in Historical Archaeology, edited by Susan M. Spencer-Wood, pp. 321-358. Plenum Press, New York.

Webb, Walter Prescott (editor)

1952

The Handbook of Texas. 2 Vols. The Texas State Historical Association, Austin. 